\title{
On the similarities of the insect brain and pattern recognition algorithms
}

\author{
Ramon Huerta \\ From 1st International Workshop on Odor Spaces \\ Hannover, Germany. 4-7 September 2013
}

We will describe the computational similarities between information processing in the insect brain and pattern recognition algorithms like support vector machines and the perceptron. The structural organization of the Mushroom bodies, the location of Hebbian learning, and the presence of inhibition can be framed in a convex optimization problem which is equivalent to the SVM. It is also noteworthy to show that simplified models of neurons can be mapped into realistic ones and vice versa. However, the mechanisms to keep the activity levels of neurons under controlled activity can be challenging in realistic neural networks, and perhaps this is the reason why there are some feedback control circuits in the Antennal Lobe and the Mushroom Bodies.

Published: 16 April 2014

Submit your next manuscript to BioMed Central and take full advantage of:

- Convenient online submission

- Thorough peer review

- No space constraints or color figure charges

- Immediate publication on acceptance

- Inclusion in PubMed, CAS, Scopus and Google Scholar

- Research which is freely available for redistribution

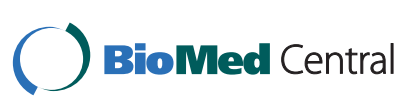

